\title{
APLIKASI SELEKSI PEMASOK KONSTRUKSI MENGGUNAKAN METODE WEIGHTED PRODUCT BERBASIS MOBILE DI PT BINARTHAMA KHARISMA
}

\author{
Andrew Balango ${ }^{1}$, Slamet Risnanto ${ }^{2}$, Phitsa Mauliana $^{3}$, Wildan Wiguna ${ }^{4}$ \\ ${ }^{1,2}$ Program Studi Teknik Informatika, Universitas Sangga Buana \\ ${ }^{3,4}$ Program Studi Sistem Informasi, Universitas Bina Sarana Informatika \\ andrewbalango@yahoo.com ${ }^{1}$, slamet.risnanto@usbypkp.ac.id ${ }^{4}$ \\ phitsa.phu@gmail.com³ ${ }^{3}$ wildan.wwg@bsi.ac.id ${ }^{4}$
}

\begin{abstract}
ABSTRAK
Sumber daya konstruksi meliputi usaha pemasok material, peralatan, teknologi, serta tenaga kerja konstruksi. Perhitungan keandalan rantai pasok harus didukung dengan data yang akurat tentang jumlah deposit, kualitas deposit, lokasi dan transportasi menuju proyek, pengaturan waktu kedatangan dan area transit. Sekarang ini banyak perusahaan yang melakukan pemilihan atau seleksi dari pemasoknya. Seleksi pemasok adalah tahap proses pembelian industri yang biasanya dilakukan dengan cara meninjau proposal dan memilih pemasok. Perusahaan pembeli akan mempertimbangkan banyak atribut dari pemasok beserta kepentingan relatifnya. PT Binarthama Kharisma merupakan salah satu perusahaan yang bergerak di bidang konstruksi. Terdapat beberapa kendala yang harus dibenahi pada perusahaan tersebut diantaranya Adm. Logistik mengalami kesulitan menerapkan beberapa kriteria yang diinginkan dalam memilih pemasok yang tepat dan dapat diandalkan untuk proses konstruksi. Beberapa atribut dan metode yang digunakan masih belum sesuai dengan kebutuhan perusahaan. Kemudian belum adanya suatu apikasi mobile seleksi pemasok konstruksi yang digunakan pada PT Binarthama Kharisma. Tujuan dari penelitian ini yaitu membangun aplikasi seleksi pemasok konstruksi menggunakan metode Weighted Product berbasis mobile di PT Binarthama Kharisma. Hasil penelitian menunjukkan bahwa Adm. Logistik dimudahkan dalam memilih pemasok konstruksi terbaik dari urutan ranking yang dihasilkan. Beberapa kriteria yang digunakan pada metode Weighted Product sangat sesuai dengan kebutuhan perusahaan. Apikasi mobile seleksi pemasok konstruksi berhasil dibangun menggunakan pemrograman Android di PT Binarthama Kharisma.
\end{abstract}

Kata Kunci: Sistem Pendukung Keputusan, Aplikasi Android, Seleksi Pemasok, Metode Weighted Product, PT Binarthama Kharisma

\section{PENDAHULUAN}

Pembangunan infrastruktur skala besar yang menjadi prioritas pemerintah Indonesia harus didukung dengan industri konstruksi dan kesiapan rantai pasok sumber daya konstruksi yang handal. Sumber daya konstruksi meliputi usaha pemasok bahan bangunan, usaha pemasok peralatan konstruksi, usaha pemasok teknologi konstruksi, serta usaha pemasok tenaga kerja konstruksi. Perhitungan keandalan rantai pasok harus didukung dengan data yang akurat tentang jumlah deposit, kualitas deposit, lokasi dan transportasi menuju proyek, pengaturan waktu kedatangan dan area transit (Dewi et al., 2018).
Sekarang ini banyak perusahaan yang melakukan pemilihan atau seleksi dari pemasoknya. Seleksi pemasok adalah tahap proses pembelian industri yang biasanya dilakukan dengan cara meninjau proposal dan memilih pemasok. Perusahaan pembeli akan mempertimbangkan banyak atribut dari pemasok beserta kepentingan relatifnya. Atribut-atribut dalam seleksi pemasok dapat mencakup kualitas produk dan layanan, reputasi, pengiriman yang tepat waktu, perilaku perusahaan yang etis, komunikasi yang jujur, serta harga yang kompetitif. Pada akhirnya, perusahaan pembeli dapat memilih pemasok tunggal atau beberapa pemasok saja (Kotler et al., 2015).

PT Binarthama Kharisma merupakan salah satu perusahaan yang melakukan 
manajemen anggaran sebagai antisipasi terhadap kebutuhan akan jasa teknik yang makin meningkat dimasa mendatang. Jasa teknik yang sangat berperan dalam menunjang lajunya pembangunan adalah jasa dalam bidang Informatika dan Telekomunikasi, Teknik Sipil dan Geoteknik, Teknik Lingkungan dan Geomatika yang saling terkait satu sama lain. Pengalaman konsultasi yang tajam dan mantap seirama dengan pengembangan usaha sektor lainnya akan memberikan saham yang besar dalam mencapai sasaran yang tepat serta nilai guna yang tinggi.

Terdapat beberapa kendala yang harus dibenahi dari hasil observasi yang telah dilakukan pada PT Binarthama Kharisma. Adm. Logistik mengalami kesulitan menerapkan beberapa kriteria yang diinginkan dalam memilih pemasok yang tepat dan dapat diandalkan untuk proses konstruksi. Beberapa atribut dan metode yang digunakan pada proses pemilihan pemasok masih belum sesuai dengan kebutuhan perusahaan. Kemudian belum adanya suatu apikasi mobile seleksi pemasok konstruksi yang digunakan pada PT Binarthama Kharisma. Oleh karena itu, pada permasalahan-permasalahan tersebut dibutuhkan proses kualifikasi dan optimasi untuk membuat keputusan yang objektif.

Suatu seleksi pemasok konstruksi dapat dioptimalkan menggunakan sistem penunjang keputusan (SPK) menggunakan metode Weighted Product. Terdapat penelitian mengenai SPK penilaian kinerja kasir Lotte Mart menggunakan metode Weighted Product. Hasil penelitian ini menunjukkan bahwa SPK memudahkan personalia melakukan penilaian kinerja Kasir menggunakan metode Weighted Product (Mirawati et al., 2018). Kemudian penelitian SPK evaluasi kinerja pramuniaga Toserba Yogya Ciwalk menggunakan metode Weighted Product yang memberikan kemudahan bagi personalia dalam melakukan penilaian kinerja terhadap Pramuniaga menggunakan metode Weighted Product (Mauliana et al., 2018).

Dari permasalahan sebelumnya, maka pada penelitian ini berfokus pada seleksi pemasok konstruksi dengan menerapkan metode Weighted Product menggunakan pemrograman mobile. Terdapat penelitian berbasis mobile yang dapat membantu dalam proses binis pada suatu perusahaan. Pada penelitian tersebut dilakukan pembangunan suatu aplikasi mobile yang berhasil menggunakan pemrograman Android (Wiguna \& Alawiyah, 2019). Sehingga tujuan dari penelitian ini yaitu membangun aplikasi seleksi pemasok konstruksi menggunakan metode Weighted Product berbasis mobile di PT Binarthama Kharisma.

\section{METODE PENELITIAN}

\subsection{Teknik Pengumpulan Data}

Pada tahap ini terdapat beberapa mekanisme dalam melakukan penelitian sistem pendukung keputusan (Wiguna et al., 2020) diantaranya:

1. Observasi, dilakukan pengamatan langsung atau peninjauan secara cermat pada PT Binarthama Kharisma. Ditinjau dokumen operasional yang sedang berjalan dan analisa Standard Operational Procedure (SOP) pada perusahaan.

2. Wawancara, melakukan tanya jawab secara tatap muka terhadap Mandor Proyek, Supervisor, Surveyor, serta Adm. Logistik yang berhubungan dengan seleksi pemasok konstruksi pada tempat riset.

3. Studi pustaka dan sumber referensi yang digunakan pada penelitian ini yaitu beberapa jurnal dan buku yang berkaitan dengan sistem penunjang keputusan, metode Weighted Product, dan pemrograman Android.

\subsection{Metode Pengembangan Sistem}

Metode pengembangan sistem menggunakan model waterfall pada pemrograman Android yang terbagi menjadi beberapa tahapan (Wiguna \& Alawiyah, 2019) diantaranya:

1. Analisis, menjelaskan analisa kebutuhan sistem mengenai kebutuhan fungsional aplikasi yang akan yang akan dikembangkan di tempat riset. Pada bagian ini digambarkan use case diagram dan activity diagram yang terkait dengan proses bisnis yang dinarasikan.

2. Desain, spesifikasi perancangan sesuai dengan kebutuhan yang terkait dengan pengembangan aplikasi. Pada 
perancangan database menggunakan Entity Relationship Diagram (ERD).

3. Implementasi, bahasa pemrograman yang akan digunakan pada pembuatan aplikasi ini menggunakan Java dan XML menggunakan editor Android Studio. Aplikasi yang akan dibangun termasuk ke dalam pemrograman berorientasi objek.

4. Pengujian, teknik pengujian yang dilakukan terhadap aplikasi yang akan dibangun yaitu menggunakan white box testing untuk menguji alur atau flow dari aplikasi.

5. Support, mendefinisikan beberapa upaya pengembangan terhadap aplikasi yang sedang dibuat dalam menghadapi dan mengantisipasi perkembangan maupun perubahan sistem yang akan digunakan. Perangkat yang digunakan untuk pemasangan aplikasi yang telah berhasil diujikan, dan disesuaikan dengan aplikasi yang nantinya dipilih.

\section{HASIL DAN PEMBAHASAN}

\subsection{Analisis}

Diuraikan mengenai tahapan analisis kebutuhan sistem yang digambarkan dengan use case diagram dan activity diagram.

\section{A. Tahapan Analisis}

Pada tahapan ini perlu dirincikan spesifikasi kebutuhan dari sistem pendukung keputusan menggunakan metode Weighted Product.

Halaman Frontend:

A1. Adm. Logistik dapat melakukan login.

A2. Adm. Logistik dapat memeriksa rangking dari hasil perhitungan seleksi.

A3. Adm. Logistik dapat mengakses halaman informasi.

Halaman Backend:

B1. Adm. Logistik dapat mengelola kriteria seleksi.

B2. Adm. Logistik dapat mengelola alternatif pemasok konstruksi.

B3. Adm. Logistik dapat mengelola nilai rating.

B4. Adm. Logistik dapat melakukan logout.

\section{B. Tahapan Analisis}

Digambarkan use case diagram pada aplikasi yang akan dibangun terkait dengan proses bisnis utamanya saja.

Pada Gambar 1 merupakan use case diagram untuk seleksi pemasok material konstruksi menggunakan metode Weighted Product. Fungsi-fungsi yang terdapat pada sistem pendukung keputusan.

\section{Activity Diagram}

Penggambaran activity diagram menggunakan partisi berdasarkan actor yang melakukan interaksi dengan aplikasi, diantaranya:

1. Acivity Diagram Melakukan Login

Aktivitas Adm. Logistik dalam melakukan proses login dapat dilihat pada Gambar 2.

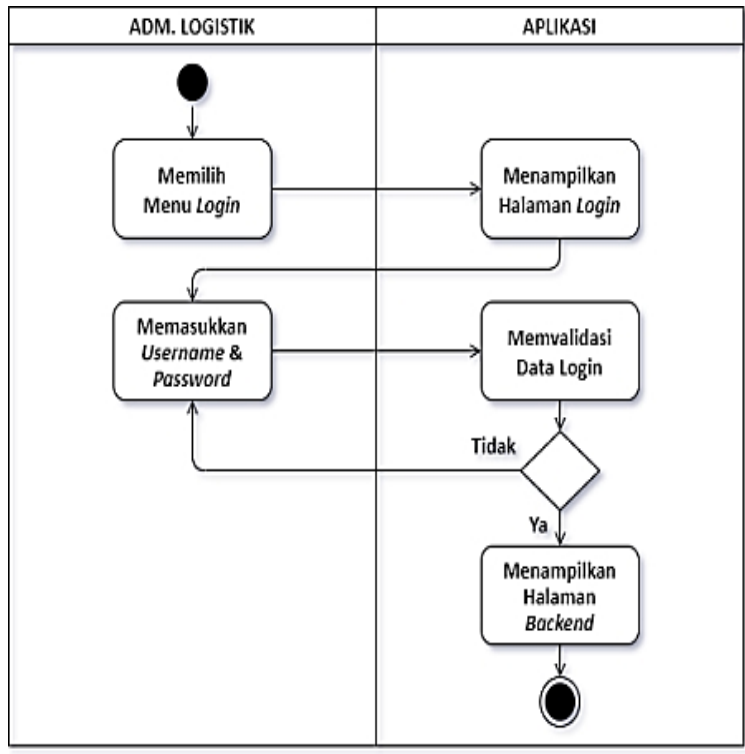

Gambar 2. Activity Diagram Melakukan

$$
\text { Login }
$$

Pada Gambar 2 dapat dilihat Adm. Logistik memasukkan username dan password yang divalidasi oleh sistem. Apabila username atau password salah maka Adm. Logistik harus mengulangi kembali memasukkan data login yang benar. 


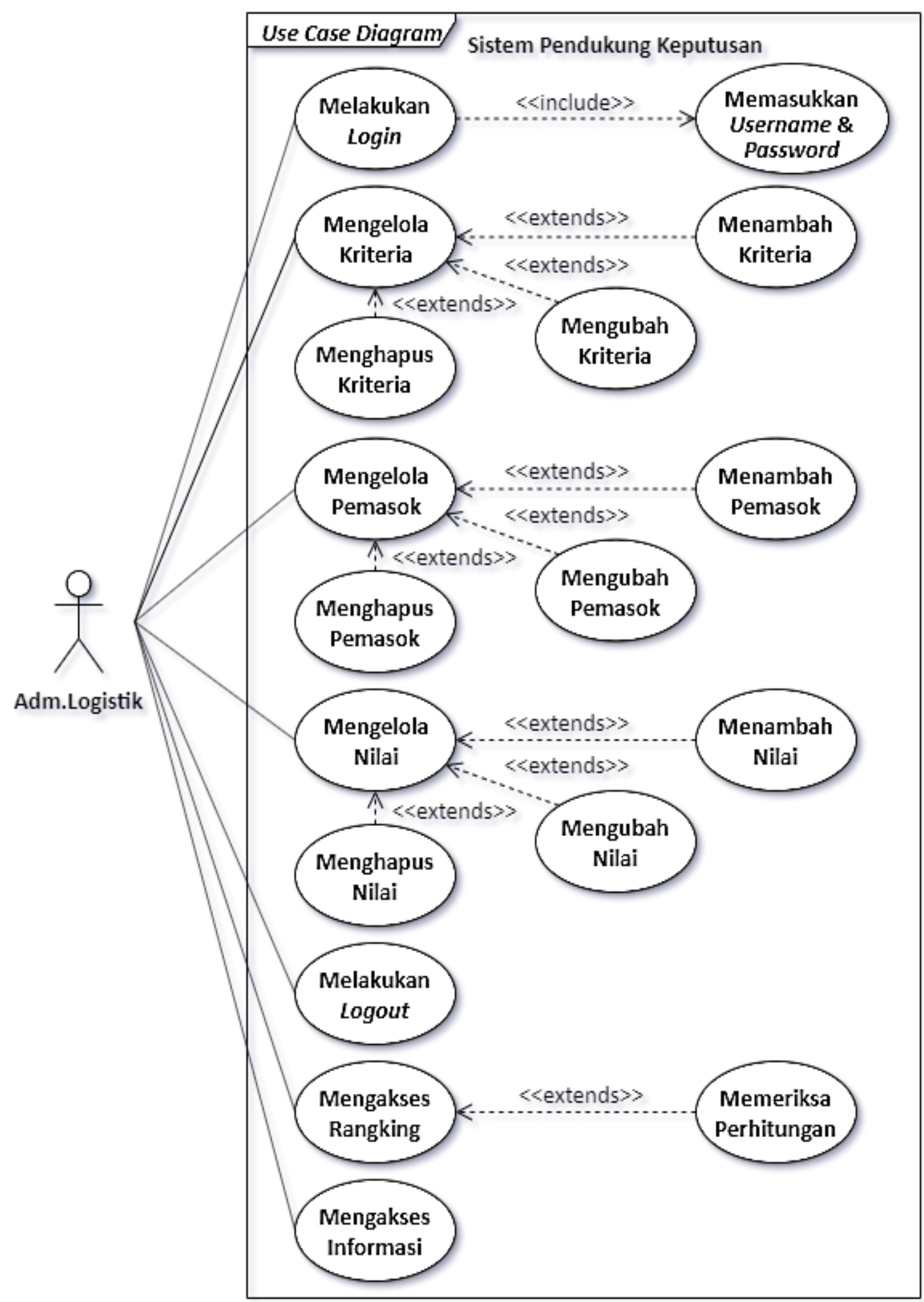

Gambar 1. Use Case Diagram Sistem Pendukung Keputusan 
2. Acivity Diagram Mengelola Kriteria Aktivitas Adm. Logistik dalam mengelola kriteria dapat dilihat pada Gambar 3.

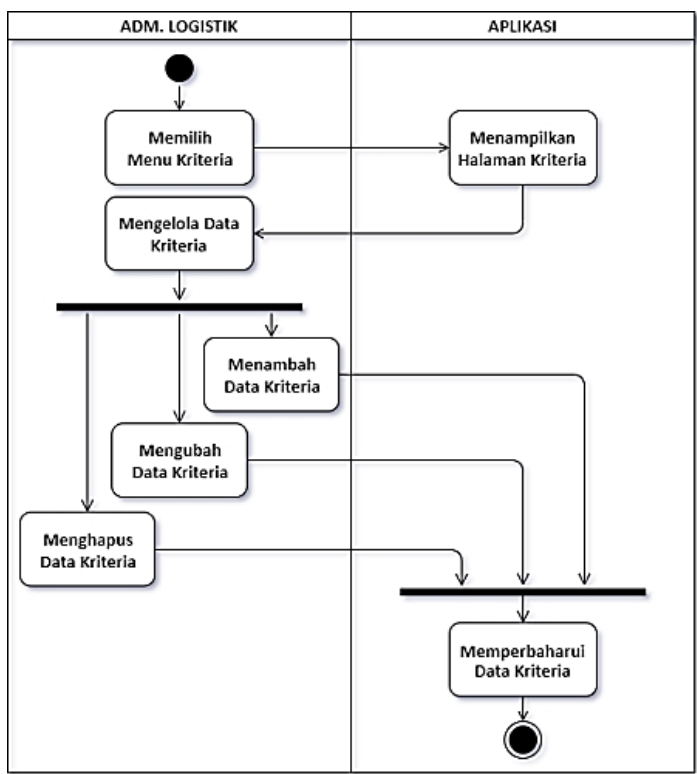

Gambar 3. Activity Diagram Mengelola Kriteria

3. Acivity Diagram Mengelola Pemasok Aktivitas Adm. Logistik dalam mengelola pemasok dapat dilihat pada Gambar 4.

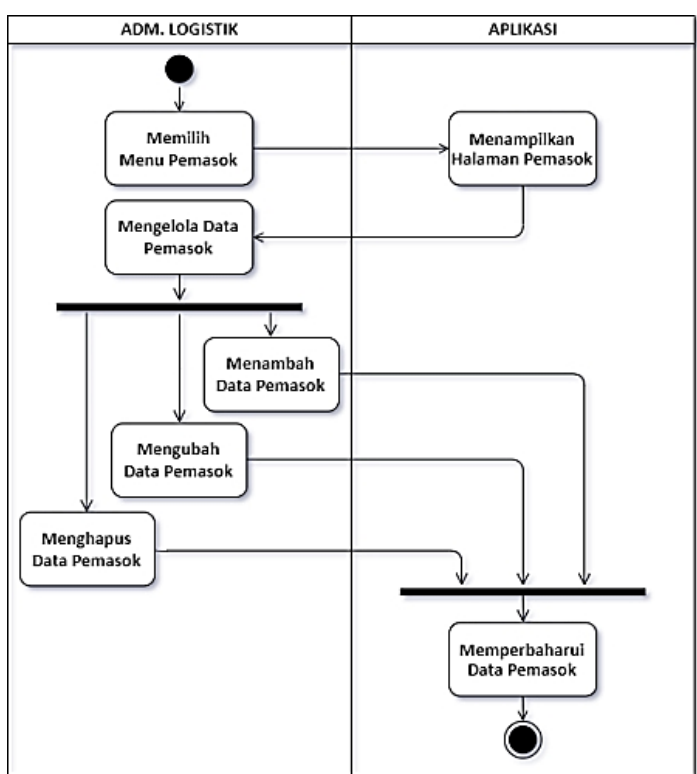

Gambar 4. Activity Diagram Mengelola Pemasok

4. Acivity Diagram Mengelola Nilai Aktivitas Adm. Logistik dalam mengelola nilai dapat dilihat pada Gambar 5.

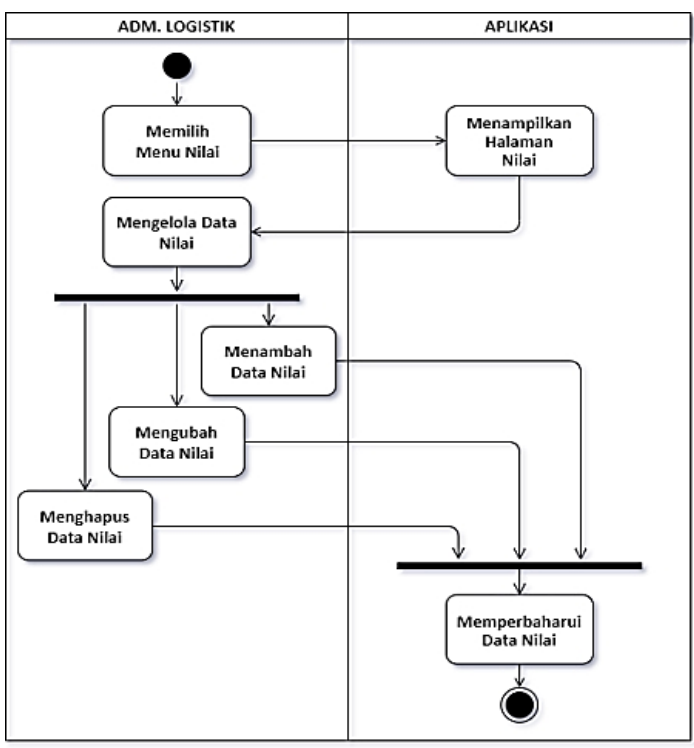

Gambar 5. Activity Diagram Mengelola Nilai

5. Acivity Diagram Melakukan Logout

Aktivitas Adm. Logistik dalam melakukan proses logout dapat dilihat pada Gambar 6.

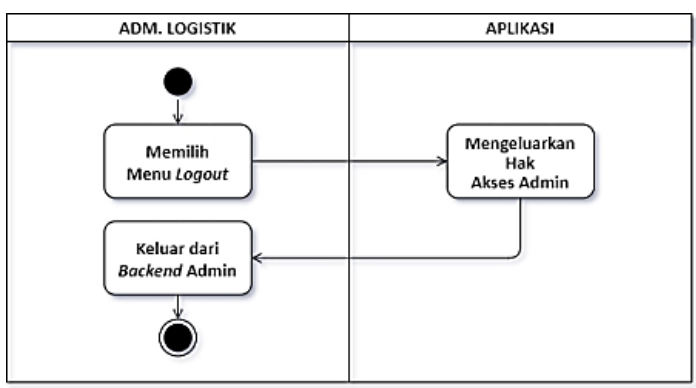

Gambar 6. Activity Diagram Melakukan Logout

6. Acivity Diagram Mengakses Rangking Alur dari proses akses menu rangking yang dapat dilihat pada Gambar 7.

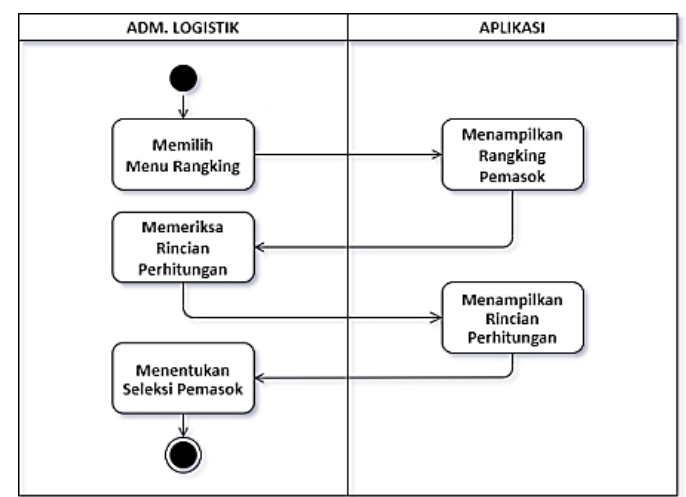

Gambar 7. Activity Diagram Mengakses Rangking 
7. Acivity Diagram Mengakses Informasi Aktivitas Adm. Logistik dalam mengakses informasi dapat dilihat pada Gambar 8.

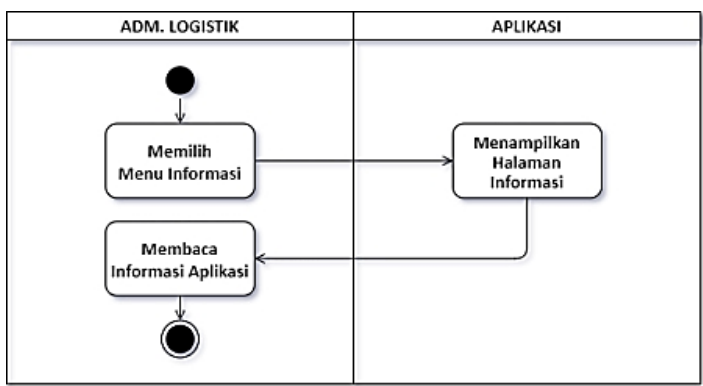

Gambar 8. Activity Diagram Mengakses Informasi

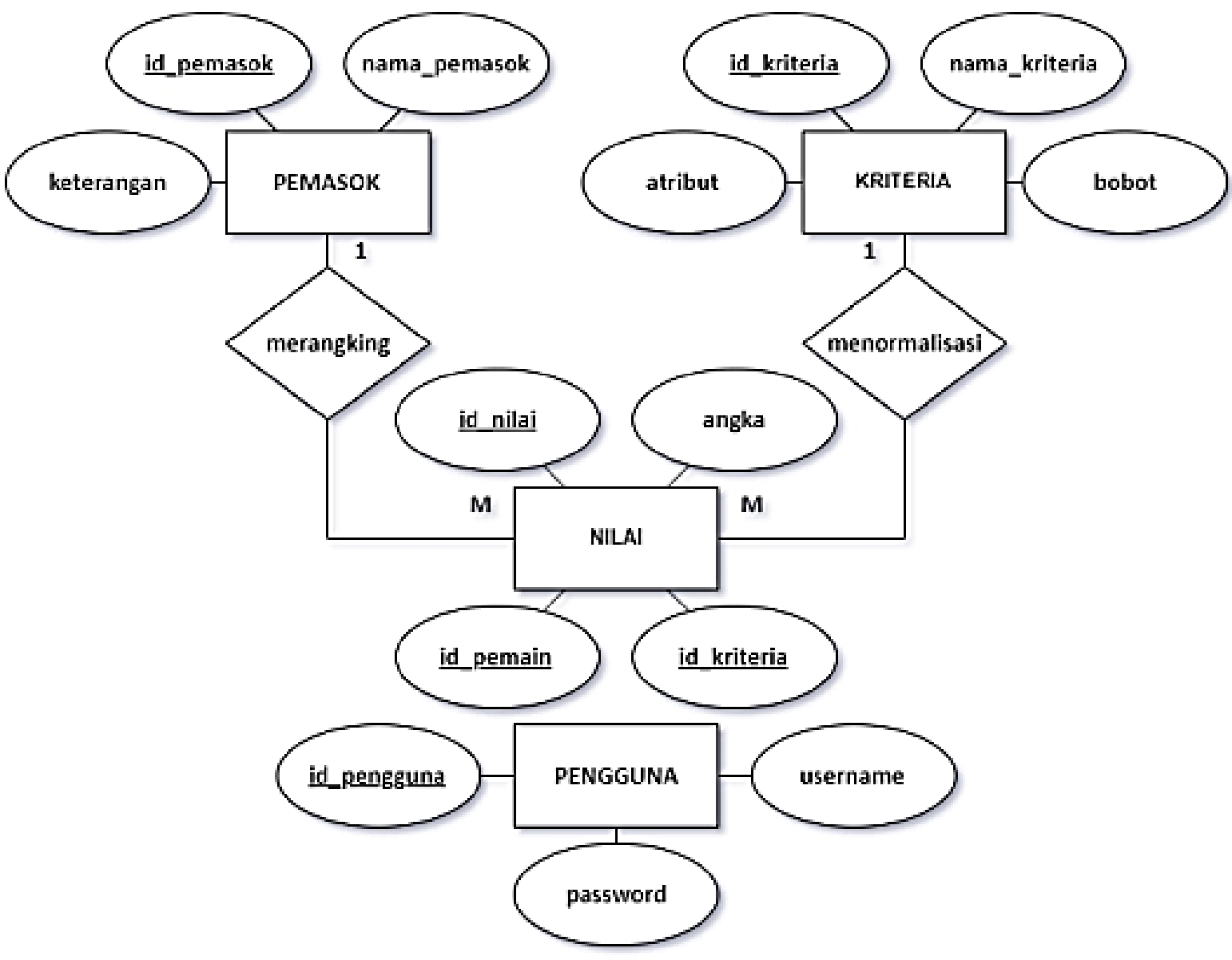

Gambar 9. ERD Aplikasi Seleksi Pemasok

\subsection{Desain}

Pada tahapan ini menjelaskan tentang desain database, software architecture, serta interface dari sistem yang dibuat.

\section{A. Database}

Pada perancangan database menggambarkan tabel-tabel beserta relasinya menggunakan Entity Relationship Diagram (ERD).
Pada Gambar 9 menunjukkan ERD yang merupakan rancangan database dari aplikasi untuk sistem pendukung keputusan yang akan dibangun. Pada rancangan tersebut terdapat tabel pemasok, kriteria, dan nilai yang saling terkait. Namun untuk tabel pengguna tidak memiliki relasi dengan tabel lainnya.

\subsection{Implementasi}

Menampilkan antarmuka dari aplikasi seleksi pemasok yang dibangun.

1. Antarmuka Login 
Tampilan dari halaman login admin dapat dilihat pada Gambar 10.

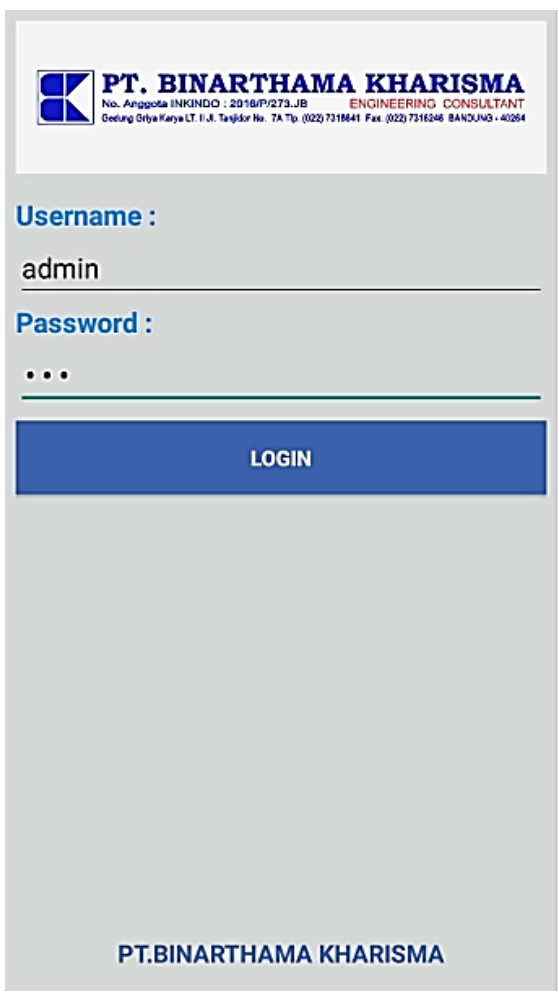

Gambar 10. Tampilan Login

2. Antarmuka Kriteria

Tampilan dari halaman kriteria dapat dilihat pada Gambar 11.

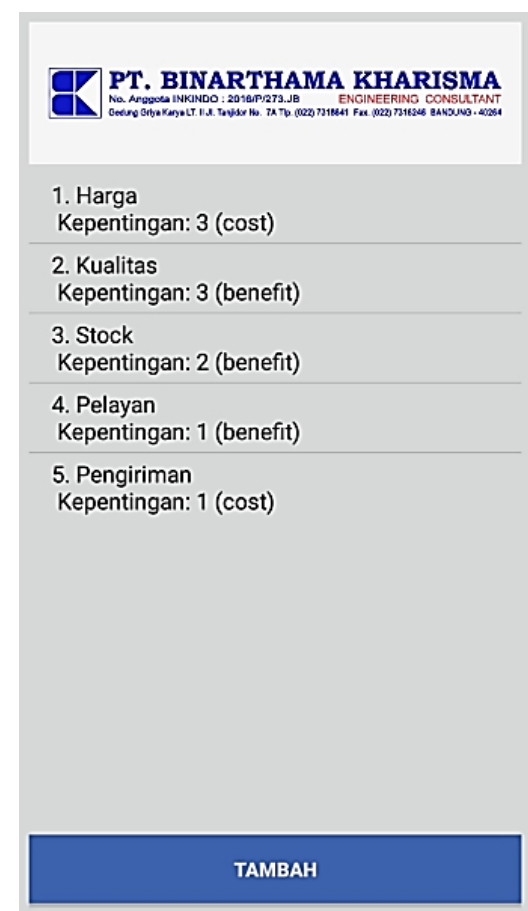

Gambar 11. Tampilan Kriteria
3. Antarmuka Pemasok

Tampilan dari halaman pengelolaam pemasok dapat dilihat pada Gambar 12.

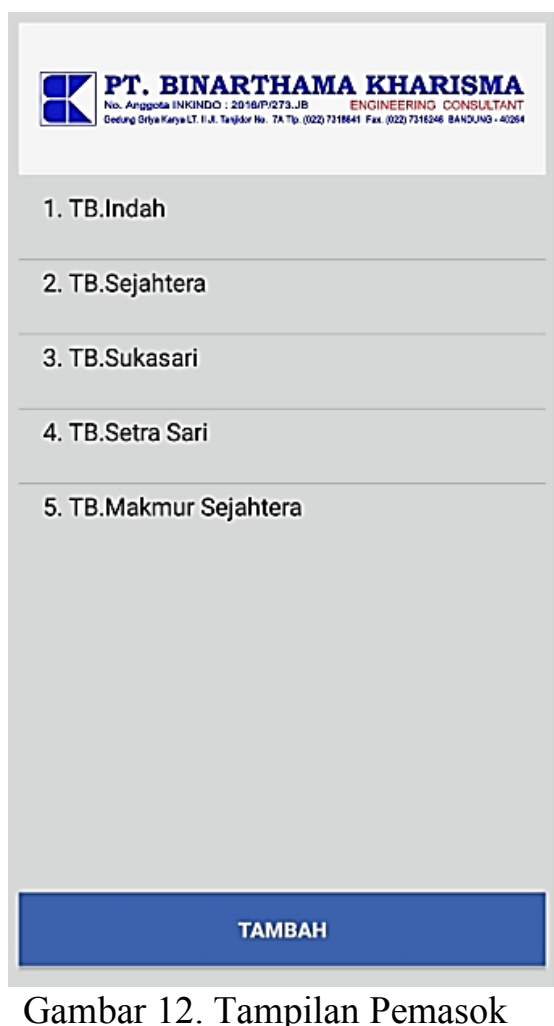

4. Antarmuka Nilai

Tampilan dari halaman pengelolaan nilai dapat dilihat pada Gambar 13

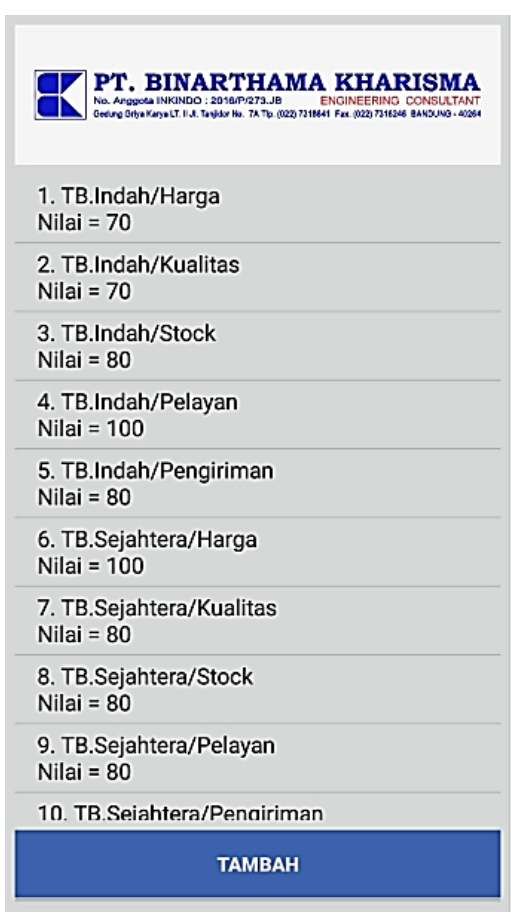

Gambar 13. Tampilan Nilai 
5. Antarmuka Logout

Tampilan dari halaman proses logout atau keluar menu pegelolaan data dapat dilihat pada Gambar 14.

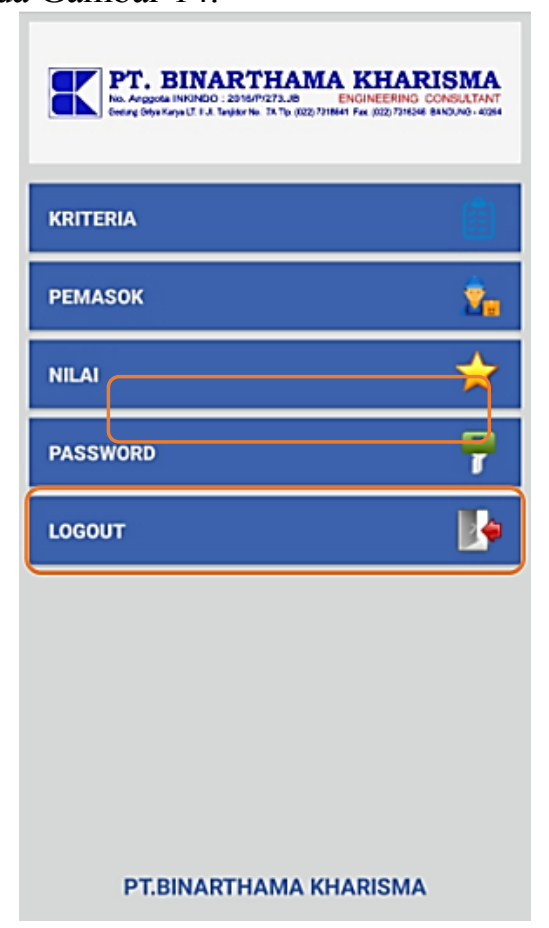

Gambar 14. Tampilan Logout

6. Antarmuka Rangking

Tampilan dari halaman rangking (urutan pemasok) dapat dilihat pada Gambar 15.

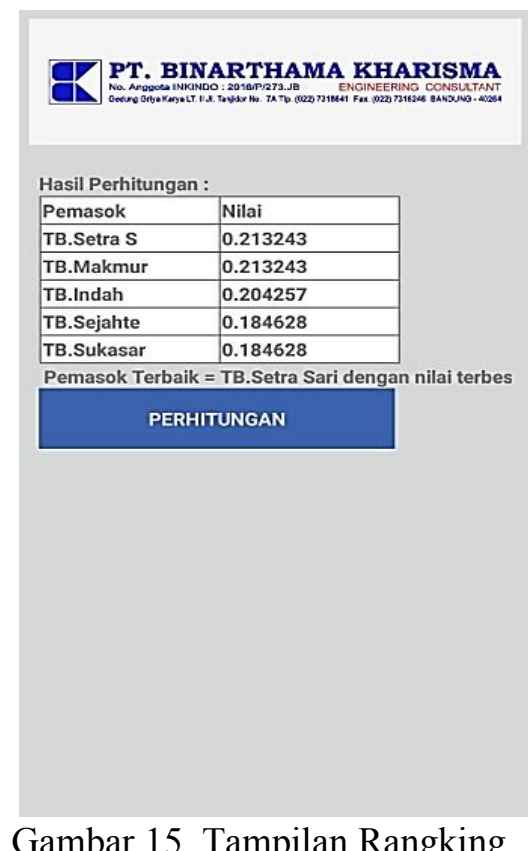

7. Antarmuka Informasi

Tampilan dari halaman informasi dapat dilihat pada Gambar 16.

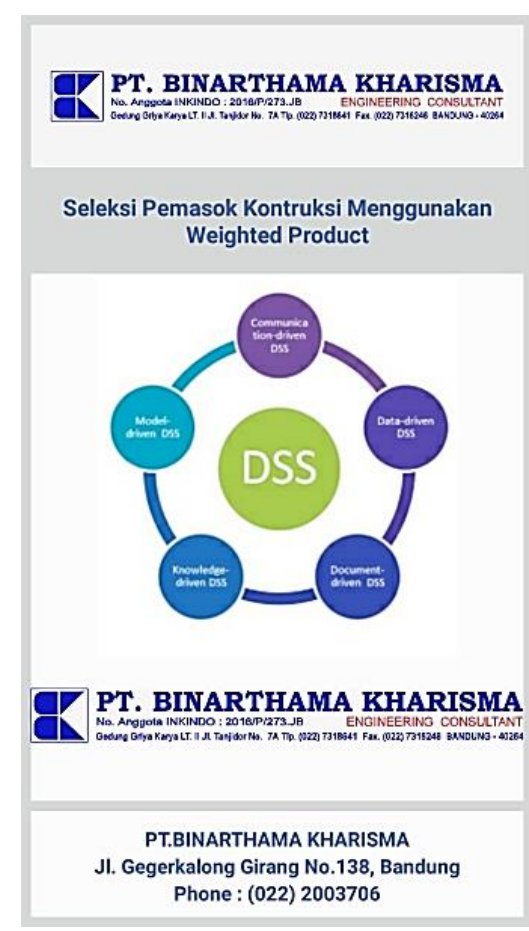

Gambar 16. Tampilan Informasi

\subsection{Support}

Merincikan kebutuhan hardware dan software standar yang akan digunakan untuk dapat menjalankan sistem usulan terdapat pada Tabel 1.

Tabel 1. Spesifikasi Smartphone

\begin{tabular}{|c|l|l|}
\hline No. & Spesifikasi & \multicolumn{1}{|c|}{ Keterangan } \\
\hline 1 & $\begin{array}{l}\text { Operating } \\
\text { System }\end{array}$ & $\begin{array}{l}\text { Android OS, v5.1.1 } \\
\text { (Lollipop) }\end{array}$ \\
\hline 2 & CPU & $\begin{array}{l}\text { Exynos 3475 Quad-Core } \\
1.3 \quad \text { GHz Cortex-A7, } \\
\text { GPU Mali-T720 }\end{array}$ \\
\hline 3 & RAM & $1 \mathrm{~GB}$ \\
\hline 4 & Storage & $8 \mathrm{~GB}$ \\
\hline 5 & Konektivitas & $\begin{array}{l}\text { HSPA 42.2/5.76 Mbps, } \\
\text { LTE Cat4 150/50 Mbps. }\end{array}$ \\
\hline 6 & Layar & $\begin{array}{l}4.7 \quad \text { inches, 540x960 } \\
\text { pixels. }\end{array}$ \\
\hline
\end{tabular}

\subsection{Pengujian}

Aplikasi yang dibangun diujikan menggunakan white box testing (Hariyanti \& Wiguna, 2019). Flowchart dari aplikasi pemasok konstruksi dapat dilihat pada Gambar 17. 


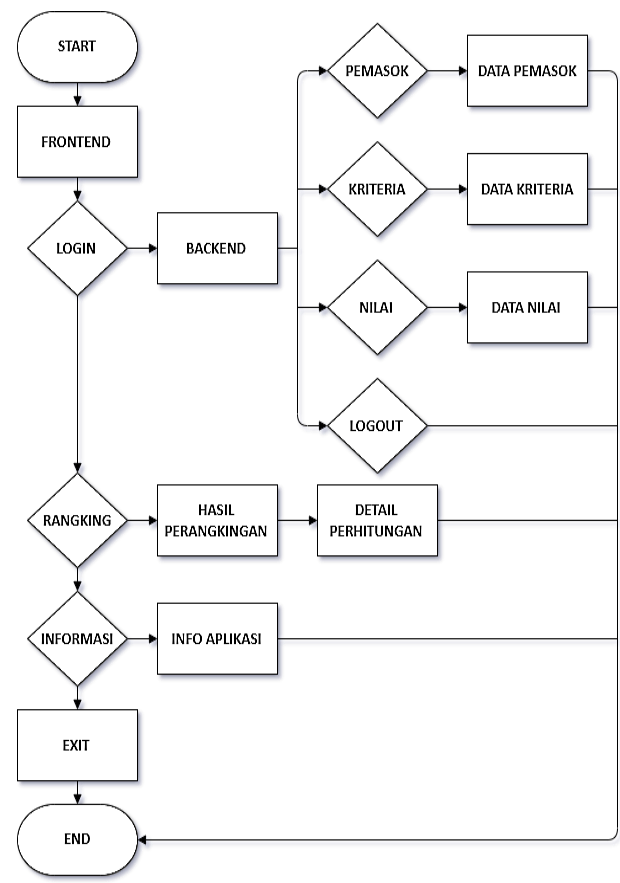

Gambar 17. Flow Chart Aplikasi Seleksi Pemasok Konstruksi

Sedangkan kompleksitas siklomatis/ cyclomatic complexity atau matrik perangkat lunak yang memberikan pengukuran kuantitatif terhadap kompleksitas logis untuk aplikasi seleksi pemasok konstruksi dapat digambarkan pada grafik alir/flow graph pada Gambar 18.

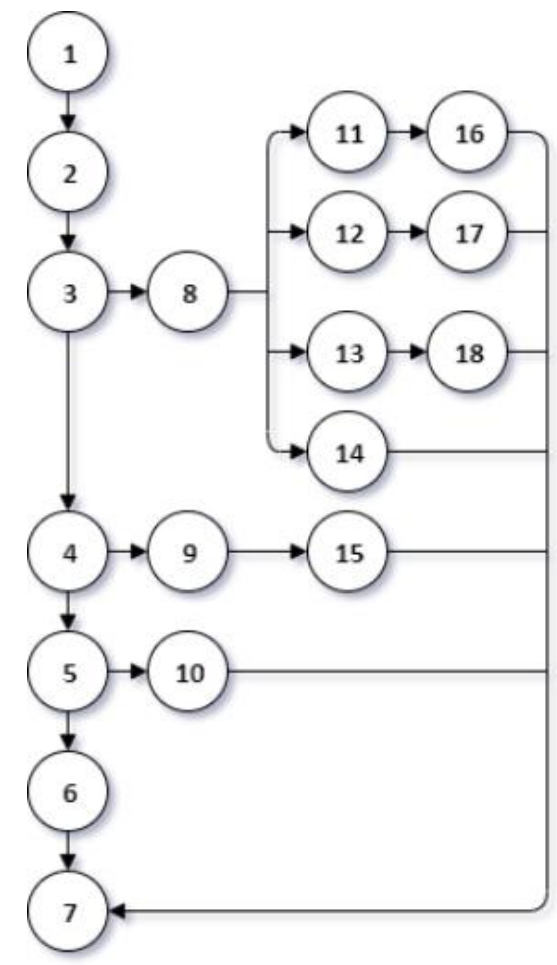

Gambar 18. Grafik Alir Aplikasi Seleksi Pemasok Konstruksi
Pada Gambar 18 kompleksitas siklomatis dari grafik alir dapat diperoleh dengan perhitungan berikut ini:

$\mathrm{V}(\mathrm{G})=20-18+2=4$

$\mathrm{V}(\mathrm{G})<10$ berarti memenuhi syarat kekomplesitasi siklomatisnya.

Baris set yang dihasilkan dari jalur independent yaitu:

1. 1-2-3-4-5-6-7

2. $1-2-3-8-11-16-7$

3. $1-2-3-8-12-17-7$

4. $1-2-3-8-13-18-7$

5. $1-2-3-8-14-7$

6. $1-2-3-4-9-15-7$

7. 1-2-3-4-5-10-12-13-14-7

8. 1-2-3-4-5-10-7

Ketika aplikasi dijalankan, maka satu set baris yang dihasilkan adalah 1-2-3-4-5-6-7-12-3-8-11-16-7-1-2-3-8-12-17-7-1-2-3-8-1318-7-1-2-3-8-14-7-1-2-3-4-9-15-7-1-2-3-4-510-12-13-14-7-1-2-3-4-5-10-7 dan terlihat bahwa simpul telah dieksekusi satu kali.

\section{PENUTUP}

\subsection{Kesimpulan}

Dari pembahasan aplikasi seleksi pemasok konstruksi yang telah maka dapat diuraikan kesimpulan sebagai berikut:

1. Adm. Logistik dimudahkan dalam memilih pemasok terbaik yang tepat dan dapat diandalkan terhadap proses konstruksi dari urutan rangking yang dihasilkan.

2. Pada proses pemilihan pemasok konstruksi diambil atribut-atribut dari beberapa referensi ilmiah dan digunakan metode Weighted Product yang sudah sesuai dengan kebutuhan perusahaan.

3. Apikasi mobile seleksi pemasok konstruksi berhasil dibangun menggunakan bahasa pemrograman java dan $\mathrm{xml}$, serta diimplementasikan pada smartphone dengan sistem operasi Android di PT Binarthama Kharisma.

\subsection{Saran}

Terdapat beberapa saran yang dapat dipergunakan agar aplikasi seleksi pemasok konstruksi dapat dikembangkan menjadi lebih baik lagi antara lain:

1. Siharapkan aplikasi seleksi pemasok konstruksi ini dapat terhubung dengan 
server perusahaan, sehingga lebih memudahkan Adm. Logistik dalam pembuatan laporan.

2. Metode Weighted Product yang diterapkan diharapkan dilengkapi atau digabungkan dengan metode lainnya. Hal tersebut memungkinkan pemeringkatan yang lebih optimal dengan berbagai kriteria yang variatif.

3. Dalam pengembangan selanjutnya, aplikasi seleksi pemasok konstruksi yang dibangun tidak hanya untuk sistem operasi Android saja, namun juga dapat dijalankan dengan sistem operasi iOS pada smartphone iPhone.

\section{DAFTAR PUSTAKA}

[1] Dewi, S. M., Dobana, K., \& Zacoeb, A. (2018). Keandalan Struktur dan Infrastruktur. Universitas Brawijaya Press.

[2] Hariyanti, I., \& Wiguna, W. (2019). Perbandingan Metode Weighted Product dengan Simple Additive Weighting untuk Evaluasi Kinerja Kasir. JURNAL RESPONSIF: Riset Sains \&
Informatika, 1(1), 33-45

[3] Kotler, P., Armstrong, G., Burton, S., \& Deans, K. (2015). Marketing (9th ed.). French Forest: Pearson Australia.

[4] Mauliana, P., Wiguna, W., \& Widyaman, D. (2018). Sistem Pendukung Keputusan Evaluasi Kinerja Pramuniaga Toserba Yogya Ciwalk Menggunakan Metode Weighted Product. Infotronik: Jurnal Teknologi Informasi dan Elektronika, 3(2), 85-94.

[5] Mirawati, M., Hikmah, A. B., \& Wiguna, W. (2018). Sistem Penunjang Keputusan Penilaian Kinerja Kasir Lotte Mart Menggunakan Metode Weighted Product. IJCIT (Indonesian Journal on Computer and Information Technology), 3(2).

[6] Wiguna, W., Mauliana, P., \& Permana, A. Y. (2020). Pengembangan E-Helpdesk Support System Berbasis Web di PT Akur Pratama. JURNAL RESPONSIF: Riset Sains \& Informatika, 2(1), 19-29.

[7] Wiguna, W., \& Alawiyah, T. (2019). Sistem Reservasi Paket Wisata Pelayaran Menggunakan Mobile Commerce di Kota Bandung. Jurnal VOI (Voice Of Informatics), 8(2). 